\title{
List otwarty do Prezesa Rady Ministrów Mateusza Morawieckiego
}

\author{
Ewa Steckiewicz-Bartnicka - \\ Koordynator Komisji ds. Farmacji Szpitalnej
}

$\mathrm{W}$ dniach 26-28 maja 2019 r. odbyła się w Toruniu konferencja naukowo-szkoleniowa „XXXVII Dni Farmacji Szpitalnej”. Nie będę w tym miejscu omawiała programu konferencji, którego tematy w mojej ocenie były bardzo przydatne w pracy farmaceuty szpitalnego, gdyż można się z nim zapoznać na stronie internetowej Polskiego Towarzystwa Farmaceutycznego, do czego gorąco zachęcam.

Natomiast czuję się w obowiązku poinformować, że na Konferencji przedstawiłam propozycję listu adresowanego do Pana Premiera Mateusza Morawieckiego, w którym opisałam problemy, z jakimi się zmagają farmaceuci szpitalni, jakie obowiązki na nich ciążą oraz jaką rolę odgrywają w systemie ochrony zdrowia i ile jeszcze mogą do niego wnieść.

Od początku tej kadencji podejmujemy działania na rzecz poprawy naszej sytuacji. Niestety efekt jest daleki od oczekiwanego przez nasze środowisko.

Propozycja listu otwartego skierowanego do Prezesa Rady Ministrów Mateusza Morawieckiego i jego treść zostały zaakceptowane i podpisane przez uczestników Konferencji. Poruszane problemy zyskały także poparcie Prezesa Polskiego
Towarzystwa Farmaceutycznego, prof. dr. hab. Janusza Pluty, który wystosował odrębne pismo przewodnie do premiera.

W załączeniu przedstawiam treść pisma, odpowiedź zastępcy Szefa Kancelarii Prezesa Rady Ministrów oraz odpowiedź z Ministerstwa Zdrowia.

Niestety odpowiedź i stanowisko MZ jest niesatysfakcjonujące dla naszego środowiska. Ministerstwo traktuje nas jak pracowników drugiej kategorii i po raz kolejny zbywa zdawkowym i nic nie wnoszącym pismem. MZ odnosi się tylko do kwestii wynagrodzeń, a przytaczana argumentacja wskazuje na nieznajomość tematu. W sprawie pozostałych zagadnień poruszanych w piśmie brak jest jakiegokolwiek stanowiska. W XXI wieku ceni się specjalistów w każdej dziedzinie. Tym bardziej dziwi fakt, że specjalista od znajomości leków, ich sporządzania, działań niepożądanych, bezpiecznej farmakoterapii, jakim jest farmaceuta, jest wciąż pomijany.

Czyżby dlatego, że jest nas tak mało i nie strajkujemy??? A będzie coraz mniej, jeżeli nasz zawód nie zostanie doceniony poprzez należytą gratyfikację.

Toruń, 26 maja 2019 r.

Pan Mateusz MORAWIECKI

Prezes Rady Ministrów

Szanowny Panie Premierze,

my, farmaceuci szpitalni, uczestniczący w XXXVII Dniach Farmacji Szpitalnej zwracamy się do Pan Premiera z prośbą o zapoznanie się z problemami naszego środowiska oraz podjęcie pilnych i skutecznych działań w celu poprawienia sytuacji farmaceutów pracujących w szpitalach.

W ubiegłym roku dokonano kolejnej nowelizacji ustawy określającej sposób ustalania najniższego wynagrodzenia zasadniczego pracowników wykonujących zawody medyczne zatrudnionych w podmiotach leczniczych, nadając ustawie nowy tytul, który obecnie brzmi: ustawa $z$ dnia 8 czerwca 2017 r. o sposobie ustalania najniższego wynagrodzenia zasadniczego niektórych pracowników zatrudnionych $w$ podmiotach leczniczych.
W załączniku do ustawy określającym „Grupy zawodowe wedtug kwalifikacji wymaganych na zajmowanym stanowisku" oraz odpowiadające im „Wspótczynniki pracy”, w części dotyczącej farmaceutów, użyto określenia: „Farmaceuta, fizjoterapeuta, diagnosta laboratoryjny albo inny pracownik wykonujacy zawód medyczny inny niż określony w l.p. 1-4, wymagający wyższego wyksztatcenia, i specjalizacji" jest nie do zaakceptowania.

Podkreślić należy, że uzyskanie prawa wykonywania zawodu farmaceuty i posługiwanie się tytutem „farmaceuta” warunkowane jest ukończeniem co najmniej pięcioletnich studiów na kierunku farmacja w szkole wyższej, obejmujących co najmniej 
sześciomiesięczną praktykę zawodową w aptece, i uzyskaniem tytułu magistra farmacji.

Norma zawarta w ww. ustawie jest błędna oraz sprzeczna z prawem dotyczącym zasad wykonywania zawodu farmaceuty. Od początku prac nad uregulowaniem sposobu ustalania najniższego wynagrodzenia zasadniczego pracowników wykonujących zawody medyczne zatrudnionych w podmiotach leczniczych, farmaceuci wskazywali na konieczność ustalenia następujących, odrębnych grup zawodowych, obejmujących farmaceutów:

- „Farmaceuta, który uzyskat specjalizacje lub tytut specjalisty $w$ określonej dziedzinie farmacji” oraz

- „Farmaceuta, bez specjalizacji”.

Należy podkreślić, że farmaceuci są odrębną grupą zawodową i pod tym względem muszą być traktowani tak samo jak lekarze i pielęgniarki, którzy nie zostali połączeni w ramach jednej kategorii z innymi grupami zawodowymi.

Dysproporcje pomiędzy wynagrodzeniami pracowników należących do zbliżonych grup zawodowych potęgują uczucie niesprawiedliwości i pokrzywdzenia. Tak właśnie czują się farmaceuci szpitalni.

W uzasadnieniu ustawy zostal przytoczony art. $78 \$ 1$ Kodeksu pracy, zgodnie z którym „wynagrodzenie powinno odpowiadać $w$ szczególności rodzajowi wykonywanej pracy $i$ kwalifikacjom wymaganym przy jej wykonaniu, a także uwzględniać ilość i jakość świadczonej pracy”. Zgodnie z art.183c Kodeksu pracy, „pracownicy maja prawo do jednakowego wynagrodzenia za jednakowa prace lub za prace o jednakowej wartości. Pracami o jednakowej wartości sa prace, których wykonywanie wymaga od pracowników porównywalnych kwalifikacji zawodowych”.

W związku z powyższym zwracamy uwagę, że farmaceuci w celu uzyskania kwalifikacji zawodowych muszą ukończyć studia medyczne na tych samych uczelniach, co lekarze. Studia farmaceutyczne przeprowadzane są bez podziatu na stopnie. Warunkiem uzyskania prawa wykonywania zawodu farmaceuty jest również odbycie praktyki zawodowej. Analogicznie wygląda ksztatcenie podyplomowe. Farmaceuci podlegają obowiązkowi ksztatcenia ustawicznego, odbywają specjalizacje w dziedzinach farmacji określonych rozporządzeniem Ministra Zdrowia.

Celem regulacji miało być likwidowanie dysproporcji placowych wśród osób wykonujących zawody medyczne i zatrudnionych na podstawie stosunku pracy w podmiotach leczniczych, tj. około 437000 osób (dane CSIOZ). Przyjęta regulacja nie realizuje postulatu likwidowania dysproporcji płacowych oraz dochodzenia do godnego poziomu wynagrodzeń w służbie zdrowia.
Ustalone współczynniki pracy dla farmaceutów szpitalnych stoją w sprzeczności z przytaczanymi wyżej aktami prawnymi oraz celami projektu. Nie są sprawiedliwy, ponieważ z założenia degradują farmaceutę szpitalnego względem lekarza i powodują pogłębianie się różnic, pomimo podobnego ksztalcenia i rozwoju zawodowego.

Wedtug danych na dzień 31 grudnia 2018 r., w 755 aptekach szpitalnych zatrudnionych było 1710 farmaceutów. Stanowimy zaledwie 0,39\% wszystkich zatrudnionych w podmiotach leczniczych.

Farmaceuci nie są dostrzegani przy reformowaniu sytemu wynagradzania. Jeżeli podnoszony jest przez decydentów temat wynagrodzeń w służbie zdrowia, to zawsze w kontekście lekarzy, pielęgniarek, a ostatnio także ratowników medycznych, diagnostów laboratoryjnych i fizjoterapeutów.

Stawiamy pytanie: kiedy zostaną podniesione wynagrodzenia farmaceutów szpitalnych?

Trzeba podkreślić, że farmaceuta szpitalny to specjalista:

skoncentrowany na zagadnieniach bezpieczeństwa leku,

mogący uczestniczyć w prowadzonej terapii pacjenta;

sprawujący, wspólnie z lekarzem oraz mikrobiologiem, nadzór w zakresie skuteczności antybiotykoterapii,

uczestniczący we wprowadzaniu nowych wytycznych i standardów leczenia,

opracowujący procedury szpitalne,

- biorący udział w pracach komitetów działających na terenie szpitala, w tym terapeutycznego, do spraw antybiotykoterapii, profilaktyki okołooperacyjnej, zakażeń, żywienia dojelitowego i pozajelitowego,

- nadzorujący politykę lekową stosowaną w szpitalu,

- przygotowujący leki w dawkach dziennych, w tym leki cytotoksyczne, leki do żywienia pozajelitowego i dojelitowego,

- wytwarzający plyny infuzyjne, przygotowujący roztwory do hemodializy i dializy otrzewnowej,

- sprawujący, w określonym zakresie, pieczę nad badaniami klinicznymi.

Od doświadczenia, wiedzy i zaangażowania farmaceuty zależy racjonalna i efektywna kosztowo gospodarka lekami w szpitalu.

Ważna rola farmaceutów w systemie podnoszenia jakości i bezpieczeństwa opieki zdrowotnej jest bezdyskusyjna. Farmaceuci szpitalni wychodzą ze swoimi usługami na oddziały, stając się partnerem lekarza w prowadzeniu farmakoterapii.

Należy podkreślić, że farmaceuci odpowiadają nie tylko za zaopatrzenie, ale również za jakość produktów leczniczych. W odniesieniu do leków 
gotowych, w zakresie swoich kompetencji (określenie parametrów jakościowych w SIWZ, kontrola serii i dat ważności, nadzór nad procesem wstrzymywania i wycofywania produktów leczniczych z obrotu), zaś w odniesieniu do leków przygotowywanych na specjalne potrzeby pacjenta (leki recepturowe, leki apteczne, cytostatyki, żywienie pozajelitowe, płyny infuzyjne) - za całość jakości i bezpieczeństwa przygotowanych w aptece szpitalnej leków.

Analiza przepisów prawa w zakresie odpowiedzialności zawodowej pozwala stwierdzić, że sankcje za przewinienia zawodowe są jednakowe dla lekarzy i farmaceutów, a sankcją najbardziej dotkliwą jest kara pozbawienia prawa wykonywania zawodu.

W zakresie wysitku wkladanego w pracę, farmaceuci - pomimo częściowo odmiennego charakteru świadczonych usług - również wkładają wiele sił i pracy w wykonywanie swojego zawodu.

Farmaceuci szpitalni sprawują nadzór nad olbrzymimi środkami finansowymi. Koszty związane z zakupem leków i wyrobów medycznych stanowią kilkadziesiąt procent budżetu szpitala. Tylko na leki stosowane $\mathrm{w}$ chemioterapii i programach lekowych budżet NFZ w 2016 r. byl planowany na kwotę 3,462 miliarda złotych (dokładnie 3462168000 zl). Dość trudno jest oszacować całkowitą ilość pieniędzy, w których wydawaniu pośredniczą apteki szpitalne, jednak wg raportu IMS za I kwartał 2016 rynek leków szpitalnych (w cenach producenta netto) wyniósł 1,01 mld zł. Zakładając 5\% marży hurtowej i 8\% VAT, oraz ekstrapolując to do całego roku otrzymamy kwotę 4,58 miliarda złotych. Wartość ta odnosi się tylko do leków (pomijając wyroby medyczne).

Zgłaszane przez nas postulaty nie dotyczą tylko sfery płac. Od wielu lat domagamy się też:

1) zwiększenia nakładów na wyposażenie aptek,

2) zatrudnienia odpowiedniej liczby farmaceutów, tak abyśmy mogli spełniać wszystkie ustawowe zadania;
3) sfinansowania specjalizacji dla farmaceutów, podobnie jak ma to miejsce u lekarzy.

O tym, jak ważną rolę winni sprawować i sprawują farmaceuci w procesie racjonalnej farmakoterapii oraz nadzoru nad jakością leku wyraźnie wskazała Najwyższa Izba Kontroli w raporcie, którego treść została przesłana do Ministerstwa Zdrowia. Brak należytego wynagradzania na pewno nie przyciągnie kadr, a szpitale nadal pozostaną z obsadą 1-2 farmaceutów na 300 łóżek, co z pewnością nie przełoży się na bezpieczeństwo pacjentów i efekty ekonomiczne szpitala. Raport NIK-u pokazuje szereg systemowych zaniedbań dotyczących funkcjonowania aptek szpitalnych, takich jak: brak odpowiedniej liczby personelu, zle warunki lokalowe, brak należytego wyposażenia, sporządzanie leków do żywienia pozajelitowego i leków cytotoksycznych w nieodpowiednich warunkach (w oddziale szpitalnym) przez osoby nieuprawnione. Wskazuje także, jak uzdrowić sytuację.

Jako farmaceuci szpitalni mieliśmy nadzieję, że raport Najwyższej Izby Kontroli przyśpieszy podjęcie strategicznych decyzji, o które farmaceuci zabiegają od lat, w tym poprzez towarzystwa naukowe oraz organy samorządowe.

Farmaceuci szpitalni nie posiadają swoich związków zawodowych. Gdybyśmy zdecydowali się na akcję strajkową, musielibyśmy zamknąć apteki szpitalne i narazić pacjentów. Uważamy, że narażanie zdrowia pacjentów byłoby niemoralne. Jednak wciąż zadajemy pytanie, co się musi wydarzyć, żeby nasze problemu zostały dostrzeżone i rozwiązane.

My, farmaceuci szpitalni zwracamy się do Pana, Panie Premierze z prośbą o zwrócenie szczególnej uwagi na naszą grupę zawodową i spowodowanie, aby nasze postulaty zostały spelnione.

Z poważaniem, uczestnicy XXXVII Dni Farmacji Szpitalnej

Do wiadomości:

1. Łukasz Szumowski - Minister Zdrowia

2. Paweł Piotrowski - Główny Inspektor Farmaceutyczny

3. Elżbieta Piotrkowska-Rutkowska - Prezes Naczelnej Rady Aptekarskiej

4. Krystyna Chmal-Jagiełlo - Konsultant Krajowy ds. Farmacji Szpitalnej 
Warszawa, 28 maja 2019 r.

POLSKIE

TOWARZYSTWO

FARMACEUTYCZNE

Pan

Mateusz Morawiecki

Prezes Rady Ministrów

\section{$42 / 2015$}

Szanowny Panie Premierze,

W imieniu Zarządu Głównego Polskiego Towarzystwa Farmaceutycznego kieruję na ręce Pana Premiera list otwarty przygotowany i podpisany przez farmaceutów pracujących $w$ aptekach szpitalnych, podczas konferencji naukowo-szkoleniowej „XXXVII Dni Farmacji Szpitalnej”, organizowanej przez Polskie Towarzystwo Farmaceutyczne, która odbyła się w Toruniu w dniach 2628 maja 2019 r.

Towarzystwo wyraża poparcie dla przedstawionych w liście postulatów środowiska farmaceutów szpitalnych.

Z poważaniem

PREZES

PQLSKIEGO TOWARTYSTWR FARIACEUTYCZNEGO

limito

prof. cir dab. Janusz Pluta

Do wiadomości:

5. Łukasz Szumowski - Minister Zdrowia

6. Pawel Piotrowski - Główny Inspektor Farmaceutyczny

7. Elżbieta Piotrowska-Rutkowska - Prezes Naczelnej Rady Aptekarskiej

8. Krystyna Chmal- Jagiełło-Konsultant ds. Farmacji Szpitalnej 


\section{统采 \\ Minister Zdrowia}

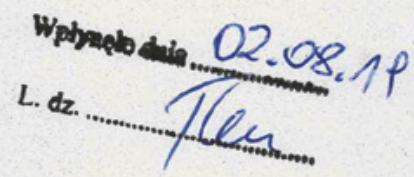

Warszawa, $\quad 19-07-2019$

DSZ.0213.82.2019.BJ

\author{
Pan \\ Prof. dr hab. Janusz Pluta \\ Prezes \\ Polskiego Towarzystwa \\ Farmaceutycznego
}

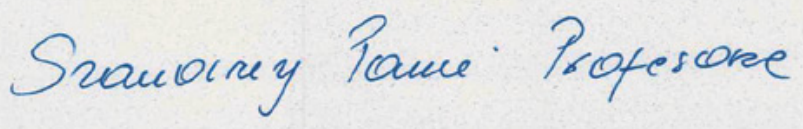

W odpowiedzi na list otwarty farmaceutów pracujących $w$ aptekach szpitalnych podpisany podczas konferencji naukowo - szkoleniowej „XXVII Dni Farmacji Szpitalnej”, organizowanej przez Polskie Towarzystwo Farmaceutyczne, zawierający postulat w sprawie poprawy sytuacji finansowej farmaceutów pracujących w szpitalach, proszę o przyjęcie poniższych informacji.

Na wstępie podkreślenia wymaga, że przepisy ustawy z dnia 8 czerwca 2017 r. o sposobie ustalania najniższego wynagrodzenia zasadniczego niektórych pracowników zatrudnionych w podmiotach leczniczych (Dz. U. z 2017 r. poz. 1473 z późn. zm.) nakładają na pracodawców obowiązek dokonywania w okresie od 1 lipca 2017 r. do 31 grudnia 2021 r. corocznych podwyżek wynagrodzeń pracowników podmiotów leczniczych. Celem przepisów tejże ustawy jest ustanowienie od dnia 31 grudnia 2021 r. minimalnych poziomów wynagrodzeń zasadniczych wyliczanych jako pochodna od przeciętego miesięcznego wynagrodzenia brutto w gospodarce narodowej w roku poprzedzającym ustalenie.

W świetle przytoczonej ustawy w przypadku osoby zatrudnionej na stanowisku farmaceuty istnieje możliwość przyporządkowania do następujących grup zawodowych:

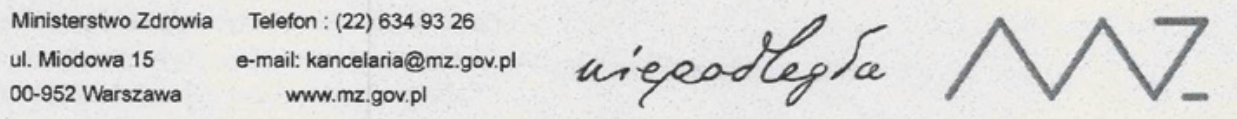


Grupa zawodowa 5 - Farmaceuta, fizjoterapeuta, diagnosta laboratoryjny albo inny pracownik wykonujący zawód medyczny inny niż określony w lp. $1-4$, wymagający wyższego wykształcenia i specjalizacji, ze współczynnikiem pracy 1, 05.

Grupa zawodowa 6 - Farmaceuta, fizjoterapeuta, diagnosta laboratoryjny albo inny pracownik wykonujący zawód medyczny inny niż określony w lp. 1 - 5 albo pracownik działalności podstawowej, inny niż pracownik wykonujący zawód medyczny, wymagający wyższego wykształcenia, bez specjalizacji, ze współczynnikiem pracy 0,73 .

Zgodnie z przepisami ustawy wysokość najniższego wynagrodzenia jest uzależniona od poziomu wykształcenia wymaganego na stanowisku pracy, na którym zatrudniony jest dany pracownik czyli wykształcenie na poziomie wyższym, średnim czy też posiadanie specjalizacji. W przypadku m. in. stanowiska farmaceuty przepisy ustawy rozróżniają fakt posiadania przez farmaceutów wyższych kwalifikacji (specjalizacji) poprzez stworzenie odrębnej grupy zawodowej dla farmaceutów legitymujących się posiadaniem specjalizacji (grupa zawodowa 5) i farmaceutów nie dysponujących takimi kwalifikacjami (grupa zawodowa 6). Wobec powyższego należy stwierdzić, że postulat dotyczący ustalenia odmiennych grup zawodowych dla farmaceutów posiadających specjalizację i nieposiadających specjalizacji, został przez ustawę spełniony.

Należy pamiętać, że wysokości wynagrodzeń zasadniczych wynikające $z$ ustawy o sposobie ustalania najniższego wynagrodzenia zasadniczego niektórych pracowników zatrudnionych w podmiotach leczniczych mają charakter wynagrodzeń minimalnych i nie mogą być utożsamiane z siatką płac obowiązującą w podmiotach leczniczych.

Jednocześnie informuję, że obecnie trwają prace zmierzające do nowelizacji ustawy z dnia 8 czerwca 2017 r. Procedowany projekt wprowadza zmianę kwoty służącej do obliczania najniższego wynagrodzenia zasadniczego pracowników podmiotów leczniczych objętych ww. ustawą tak aby na dzień 1 lipca 2019 r. uległa ona podwyższeniu z obecnej kwoty $3900 \mathrm{zł}$ na kwotę $4200 \mathrm{zł}$. Kwota bazowa w ww. wysokości będzie obowiązywać w okresie od dnia 1 lipca 2019 r. do dnia 30 czerwca $2020 \mathrm{r}$.

Mając na uwadze konieczność poprawiania dostępu do świadczeń opieki zdrowotnej finansowanych ze środków publicznych Narodowy Fundusz Zdrowia dokonał zwiększenia finansowania świadczeń zdrowotnych w rodzaju leczenie szpitalne oraz leczenie szpitalne - świadczenia wysokospecjalistyczne, m. in. poprzez zwiększenie wyceny punktowej w umowach o udzielanie świadczeń w rodzaju leczenie szpitalne 
wokreślonych zakresach. Zgodnie $z$ dokonanym przez NFZ uszczegółowieniem wspomnianych zwiększeń dokonano $\mathrm{m}$. in. $\mathrm{z}$ uwagi na zwiększające się koszty wynagrodzeń personelu. Przy czym zgodnie $z$ wyjaśnieniami Centrali NFZ świadczeniodawcy będą mogli przeznaczać środki pochodzące ze zwiększonej wyceny świadczeń m. in. na wzrosty wynagrodzeń grup zawodowych uczestniczących (pośrednio lub bezpośrednio) $w$ realizacji świadczeń opieki zdrowotnej, innych niż grupy zawodowe, dla których podwyżki uposażeń finansowane są ze środków przekazywanych odrębnymi strumieniami (oznacza to, że wspomniane wyżej środki nie są kierowane na podwyżki dla pielęgniarek i położnych, ratowników medycznych czy lekarzy specjalistów).

Nadto informuję, że kwestie dotyczące kadr medycznych, w tym również zasad wynagradzania, są przedmiotem prac prowadzonych w ramach branżowych i ponadbranżowych gremiów dialogu trójstronnego, m. in. $z$ udziałem przedstawicieli wspomnianych krajowych reprezentacji związkowych. Problematyka ta m.in. jest tematem prac działającego przy Ministerstwie Zdrowia branżowego Trójstronnego Zespołu do Spraw Ochrony Zdrowia.

Przekazując powyższe należy wskazać, że Ministerstwo Zdrowia dokłada wszelkich starań, aby prowadzony dialog owocował wypracowywaniem rozwiązań korzystnych dla pracowników sektora zdrowotnego i optymalizujących funkcjonowanie systemu ochrony zdrowia w Polsce.

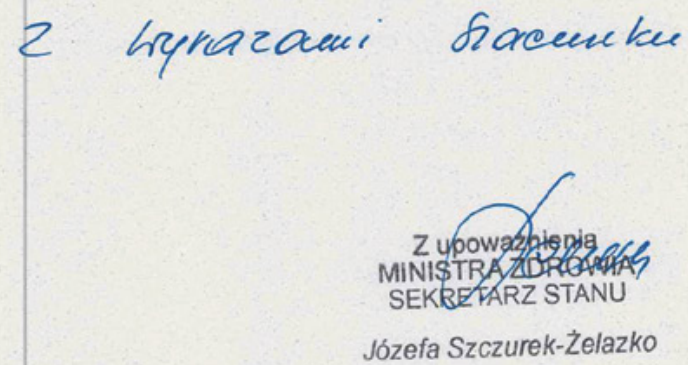

